\title{
A review on acid rain: An environmental threat
}

\author{
Fiza Fatima ${ }^{1 *}$, Nayab Fatima ${ }^{1}$, Tabassum Amjad ${ }^{1}$, Alina Anjum ${ }^{1}$, \\ Tania Afzal ${ }^{1}$, Jaweria Riaz ${ }^{1}$ and Habiba Razzaq ${ }^{1}$ \\ 1. Department of Zoology, University of Gujrat, Gujrat, Punjab-Pakistan \\ *Corresponding author's email: fiza.fatima21@yahoo.com \\ Citation \\ Fiza Fatima, Nayab Fatima, Tabassum Amjad, Alina Anjum, Tania Afzal, Jaweria Riaz and Habiba Razzaq. A \\ review on acid rain: An environmental threat. Pure and Applied Biology. Vol. 10, Issue 1, pp301-310. \\ http://dx.doi.org/10.19045/bspab.2021.100032
}

\begin{tabular}{llll}
\hline \hline Received: 11/06/2020 & Revised: 05/09/2020 & Accepted: 08/09/2020 & Online First: 21/09/2020 \\
\hline
\end{tabular}

\section{Abstract}

Acid rain is one of the utmost serious environmental problems that arose due to air pollution. It also contributes to climate warming. It has a $\mathrm{pH}$ of less than 5.6. The main purpose of the review is to emphasize the causes of acid rain, its various effects, and different ways to control acid rain. Data for the last few decades on acid rain is summarized in this review. The primary cause of acid rain is the emission of Sulphur dioxide and nitrogen oxide. These environmental pollutants come from various activities of humans such as the combustion of fossil fuels, burnable waste in automobiles, and thermal power plants. These chemicals become acidic after mixing with the rainwater and precipitate in the form of rain, fog, and snow and exert various effects on the ecosystems, forests, plants, soil, buildings, monuments, and water bodies as well as on human health. Its effects can be reduced by decreasing the Sulphur dioxide and nitrogen oxide emission and by adding lime into lakes, streams, and soil which neutralize the acidity. Several legislations should also make to control acid rain. Its control is necessary, to maintain food sustainability, environmental sustainability, to save the biodiversity of earth and human wellbeing.

Keywords: Atmosphere; Environment; Introduction

To make life easier, human beings utilized various natural resources. They have made several facilities that use the energy of the earth's resources. Burning fuels like oil, natural gas, and coal generate this energy. On one hand, this development has made life easier but on the other side, it releases various dangerous substances into the environment which leads to pollution [1]. Industrialization, urbanization, and burning of fossil fuelsrease in the number of pollutants that lead to air pollution. Acid rain is one of the utmost serious problems of the environment $[2,3]$ that arose due to air pollution [4]. Any kind of precipitation which has acidic nature is
Effects; Nitrogen; Pollutants; Sulphur called acid rain [5]. Acid rain has a $\mathrm{pH}$ of less than 5.6 [6-9].

Acid rain occurs when from various sources, emission of sulfur dioxide and nitrogen oxide take place then [10] these pollutants mix with the oxygen, carbon, and other chemicals and form acidic compounds like sulfuric acid and nitric acid in the atmosphere [11] which precipitate in the form of snow, fog or rain [12].

For industries and power plants, the uses of tall smokestacks have increased the production of atmospheric pollutants which are transported locally and worldwide and spreading acid rain [13]. Acid rain is recognized as one of the 
famous environmental problems in East Asia, North America, and Europe [14-16]. It has threatened food sustainability and environmental stability in other words affecting human life quality [17].

\section{History of acid rain}

In the mid- $19^{\text {th }}$ century, acid rain was firstly observed in Europe. In 1845, Ducros was the first scientist who recognized acid rain [18]. In 1853, acidic rain was founded [19]. In 1852, the term Acid rain was developed by an English chemist Robert Angus Smith [20-22] who noticed leaves that were damaged by the acid rain [23]. His studies linked industrial emissions with the source of acid rain and also contained the early monitoring of harmful environmental effects [24].

Until the $20^{\text {th }}$-century, smith work was mostly forgotten when the studies began to interrelate the atmospheric sulfate and other chemicals constituents deposition with the air pollution near the metal smelter in Canada [25]. In the 1960s and early 1970s in Sweden, observations exposed that nitric oxide and sulfur dioxide emission cause acid rain $[26,27]$ later on it was also observed in North America [28].

Afterward, various environmental effects of acid rain on aquatic animals and plants were also recognized and it was identified that acidification in fishes was due to longrange transportation of pollutants of sulfur [29]. Acid rain was first reported in North America, Europe, and later on in Asia [30, 31].

In 1936, the first step was taken in London to control the acid rain. Though, the harshness of the problem increased after 1970 due to increase concentration of sulfur dioxide in the atmosphere which resulted from increased use of coal fuel. The acid deposition act in 1980 was passed by the US Congress after ten years of continuous National Acidic Precipitation Assessment Program (NAPAP). This increases the observation for dry deposition and acid rain effects on buildings, aquatic ecosystems, and monuments. In the mid-1990s it was obvious that acid rain also interacts with climate warming and ozone layer depletion which are other environmental problems [23].

On control programs, funded studies were implemented. US congress has passed improvements to the Clean Air act in 1990 which contains preventive measures to sulfur dioxide and nitric oxide and this was executed into 2 phases aimed to reduce the emission of sulfur dioxide. In phase I (from 1995), From the 110 of the largest plants sulfur dioxide emission was limited. In the US, most of the other power plants were affected by Phase II (since 2000). The emission of sulfur dioxide was declined by $54 \%$ from 2000 to 2006 . Likewise, since 1999, several programs were implemented to reduce the emission of nitric oxide from automobiles and factories. In March 2005, Clean Air Interstate Rule was issued by US EPA to reduce the pollution from power plant emissions [23].

\section{Types of acid deposition}

Acid rain is also called acid deposition [32]. This deposition of acids may be dry or wet.

Snow, rain, and fog are wet deposition. When air takes the acid chemicals into such an area that has wet weather then acid on the ground falls in the form of snow, fog, and rain. This acidic water flows through the ground and affects the diversity of animals and plants [33].

Acidic particles and gases are called dry deposition. Towards cars, buildings, homes, and trees, these acidic particles and gases are blown by wind which results in sticking of these chemicals with the material. Through the rainstorms, from the other surfaces and trees, these dry deposited particles and gases can be washed out. When this occurs, then running water mixes these acids with the acid rain and makes it more acidic [34, 35]. 


\section{Causes of acid rain}

The primary causes of acid rain are nitrogen oxide, Sulphur dioxide, and ozone. Emission of these Sulphur dioxide and nitrogen oxide pollutants causes acid rain [36]. These environmental pollutants come from various activities of humans such as the combustion of fossil fuels, burnable waste in automobiles, and thermal power plants. The pollutants of Sulphur come from various natural sources such as volcanic eruptions and oceans [37]. Human activities that produce Sulphur dioxide include iron and metallic ores smelting, burning of petroleum and coal, and other industrial processes.

While the natural sources of nitrogen oxide pollutants include biological processes and lightening. Human activities which produce nitrogen oxide are power station, emission from industries and, vehicle exhausts. Sulphur in the atmosphere reacts with the hydrogen peroxide and form Sulphur dioxide, while oxidation of nitrogen dioxide produces nitric acid. When these chemicals mix with the rainwater in the atmosphere then fall on the ground in the form of acid rain [38, 39].

\section{Effects of acid rain}

Acid rain occurs due to the emission of Sulphur dioxide and nitrogen oxide and exerts various effects on,

\section{Forests}

Forests are severely damaged by acid rain. Trees at high altitudes are at greater risk because they are washed in acid clouds due to which spruce forests decline in number on the highest ranges of the Appalachian Mountains [40]. In the roots of plants, heavy metals accumulate and decrease photosynthesis due to the loss of chlorophyll [41]. Germination of seeds in Pine trees does not occur at the $\mathrm{pH}$ of acid rain [42]. In plants, protein concentration is also reduced by acid rain [43].

Sulphur and Nitrogen present in acidic mist affect stem growth [44] and younger plants get more affected than older plants $[45,46]$. A decrease in the number of forests due to acid rain results in biomass reduction. Roots and plant leaves are directly damaged by acid rain [47]. Due to acid rain, mycorrhiza of roots gets affected and results in decreased soil fertility. Acid rain causes a change in the structure of leaves and needles [48], they get brown [49] and fall off, canopy cover is also decreased, crown dieback occurs and results in the complete death of trees in forests.

\section{Buildings and monuments}

Marble and limestone which make monuments and buildings are consisting of calcium carbonates which are worn by acid rain [50]. In acid rain, Sulphur dioxide provides aqueous ions by the dissolution of calcium carbonates which are washed out in the flow of water. At the monument or building surface, this phenomenon occurs [51]. Sulphur and nitric acid in rain cause fading in paint of buildings by depositing on the coating [52] and damaged the historical buildings. Therefore, a very famous building in India like the Taj Mahal and in New York Statue of Liberty has been eroded by the acid rain [53].

In the urban area, due to the high concentration of Sulphur dioxide, the rate of corrosion is also high [54]. Acid rain with very low $\mathrm{pH}$ has also affected the buildings made up of cement and concrete [55]. Pollutants of Sulphur in rain have also damaged the Delhi Red Fort and Jama Masjid [56].

\section{Physiological activities of animals}

Various metabolic activities of animals are affected by acid rain. For example, brown trout is very sensitive to acid rain, and in females; its sexual behavior is extremely affected by it. The nest digging behavior in them is also inhibited by the acidity of water [57]. Due to acid rain, the normal function of the human body is also getting affected. Some troubles have also been seen in the immune system due to acid rain, after exposure to acidity, the level of antibodies decreases considerably in plasma [58]. 


\section{Soil}

Acid rain damages the chemistry of the soil $[59,60]$ and changes the soil quality [61]. Some harmless minerals such as aluminum and mercury are present in the soil to which plants cannot absorb when they react with the acids, then they become easily available to plants for absorption and change the soil biology and chemistry as well as cause harmful effects $[62,63]$. They also harm the animals which feed on these plants. Acid rain denatures the enzymes of microbes in the soil and killed them due to their intolerance at low $\mathrm{pH}$ [60].

Emissions of greenhouse gas from the soil are altered by the acid rain by changing the composition and biomass of microbial community; as a result acid rain makes changes in the availability of nutrients and soil edaphic properties like $\mathrm{pH}$ etc. [64]. Acid rains leach away the essential nutrients from the soil [65] and decrease the soil fertility result in decreased plant growth [66, 67].

Acidification of soil has been observed in Eastern North America [68], in China [69], and Europe. From 1982 to 1983, in the forest of Europe, a large amount of acidity was observed throughout the profile of the soil. In the layer of humus, maximum acidity was observed and it was due to the deposition of acidic chemicals from the atmosphere [70].

\section{Aquatic ecosystem}

Heavy metals which are leached out from the soil [71] through the acid rain, reached to nearby lakes and streams and cause water pollution [72]. These acids lower the $\mathrm{pH}$ of water bodies, due to which reproduction of plants and animals is also affected. These acids do not allow fishes to breathe due to which accumulation of heavy metals occur in the body and result in the death of fishes [73, 74]. When the birds eat these poisoned fishes then chemicals also enter into their system and when other animals eat these birds then these heavy metals introduce into these animals. In the food chain, chemicals are introduced at each trophic level in this way and chemical concentration also increased at each level [75].

Many other aquatic animals such as amphibians are also affected at low $\mathrm{pH}$ $[76,77,78]$ and Mollusks below $5 \mathrm{pH}$ also vanished from the Ontario Lakes [79], this indicates that mollusks are more vulnerable to acidity [80]. There are several species discovered which are tolerant of high acidity. Lobella species and Sphagnum species were dominated in Swedish Lakes which were tolerant to acidity $[81,82]$.

\section{Plants}

Acid rain greatly affects the plants and crops by affecting its structural features $[83,84]$. Trees are subjected to winter injury and even death when from the plant's needles, calcium is leached out $[\mathbf{8 5}$, 86]. Low $\mathrm{pH}$ decreases photosynthesis [87, 88] and also reduces the productivity of plants such as the Soya bean [89]. Lichens, fungi, and algae which are lower plants, acid rain also affect them as well as affect the microbial activities $[90,91]$. Acid rain also affects the mycorrhizal association $[92,93]$. Fixation of nitrogen through lichen is also affected at low $\mathrm{pH}[94,95]$. The presence of brown algae and Diatoms indicates that water is acidic [96].

\section{Human health}

The appearance and taste of acid rain are just like clean water. It exerts indirect effects on human health. Acid rain causes the leaching of toxins from the soil, these toxins include $\mathrm{Al}, \mathrm{Mn}, \mathrm{Fe}, \mathrm{Pb}$, and $\mathrm{Hg}$ [97], which get dissolve in the soil and reach the groundwater, human drink this water [98] due to which various heavy metals accumulated in their bodies and result in headache, cough, throat and nose irritation. These toxins are also absorbed by the animals and plants, when humans ingest these toxins then kidney problems and damage in the brain occur. These toxins also lead to heart diseases as well as lung diseases such as bronchitis and asthma. It is very hazardous to swim in an acid lake or to walk in acid rain. Wind 
transport nitrate and sulfate particles present in the atmosphere which are inhaled during breathing and leads to cancer [99]. In Tokyo, skin and eye irritation have also been observed due to polluted droplets [100].

\section{Acid rain and climate change}

Acid rain has an association with the climate. The emission of sulfur dioxide, nitrogen dioxide, and carbon dioxide causes acid rain. Carbon dioxide is a primary gas that also leads to the greenhouse effect. Human activities produce these chemicals of acid rain which reach the atmosphere, when their concentration becomes high then the temperature of the atmosphere increases and results in climate warming. This warming occurs at a global level. In this way, Acid rain gases also responsible for climate change [101].

\section{Control of acid rain}

Acid rain can be controlled through the following ways,

\section{Liming}

Liming is a process that is used to neutralize the acid by adding limestone into the lakes, water, and soils and reduces the lethal effects of heavy metals. This method can be applied to a specific area. Liming also allows the survival of the native population of fishes in ponds. The addition of lime reduces the damage to the water bodies. The $\mathrm{pH}$ of acidic water is raised by the addition of slacked lime, Caustic soda, limestone, and sodium carbonate [102]. In water bodies, liming enhances the water quality and also increases the productivity of plants and animals. It also restores various species. Liming is an exclusive process but is no real remedy. This process should be periodically repeated to keep effectiveness [103].

\section{Reduce the emission of pollutants}

Acid rain can be controlled by reducing the emission of pollutants such as Sulphur dioxide and nitrogen oxide which causes acid rain.

\section{Policy intervention}

In Europe and the United States, during the 1970s and 1980s, acid rain effects on various natural resources were a serious issue. In 1980, the environment protection agency in the state of Canada took the action to control the emission of chemicals which causes acid rain [104, 105]. In 1990, Legislations to control acid rain effects and control program of acid rain was also introduced [106]. The major aim of this program was to reduce the emission of Sulphur dioxide and nitrogen oxide to achieve health benefits for the environment and the public [107].

\section{Recommendations}

To reduce Sulphur dioxide emission such kind of coal should be used which have less Sulphur. Coal should be washed before using it because washing will reduce the Sulphur contents. Clean fuels should be used. Natural gas for the burning should be used rather than coal because less Sulphur dioxide produces from the burning of natural gas. Gases that are leaving the smokestacks contain Sulphur dioxide, scrubbers devices should be used to remove Sulphur dioxide chemically from these gases. In industries, a dust collection system should be fixed to reduce the release of chemicals. To reduce emissions, vehicles should be maintained timely. The burning of fossil fuels generates electricity but leads to emissions of harmful substances that result in acid rain. To prevent these emissions, any other energy sources such as nuclear power and hydropower should be used to produce electricity in the replacement of fossil fuels. In this way, emissions can be controlled.

\section{Conclusion}

After the study, the literature of review concludes that acid rain is one of the serious environmental issues. Acid rain has a pH of less than 5.6. It occurs due to the emission of Sulphur dioxide and Nitric oxide which reacts with water and produces sulfuric acid and nitric acid which precipitate in the form of rain, fog, 
and snow. These environmental pollutants come from various activities of humans such as the combustion of fossil fuels, burnable waste in automobiles, and thermal power plants. Acid rain adversely affects forests, plants, buildings, monuments, aquatic systems, soil, and human health. Acid rain effects can be reduced by adding lime into lakes, streams, and soil which neutralizes the acid. Several legislations should also build to control the acid rain. The buffering capacity of acid and the mechanism which is involved in the plant system treated with simulated acid rain is still unclear and needs deeper study.

\section{Author's contributions}

Wrote the manuscript with inputs from all the authors: F Fatima, Critically examined the data:N Fatima, T Amjad, A Anjum, T Afzal \& J Riaz, Reviewed the manuscript: H Razzaq.

\section{References}

1. Tripathi AK \& Gautam M (2007). Biochemical parameters of plants as indicators of air pollution. $J$ Environ Biol 28: 127-132.

2. Grennfelt P, Engleryd A, Forsius M, Hov, Rodhe H \& Cowling E (2019). Acid rain and air pollution: 50 years of progress in environmental science and policy. Ambio 1-16.

3. Wei H, Ma R, Zhang J, Saleem M, Liu Z, Shan X \& Xiang H (2020). Croplitter type determines the structure and function of litter-decomposing microbial communities under acid rain conditions. Sci of the Total Environ 7(13): 136600.

4. Dwivedi AK \& Tripathi BD (2007). Pollution tolerance and distribution pattern of plants in surrounding area of coal-fired industries. J Environ Biol 28: 257-263

5. Bhargava S \& Bhargava S (2013). Ecological consequences of the acid rain. J Appl Chem 5: 19-24.

6. Burns DA, Aherne J, Gay DA \& Lehmann C (2016). Acid rain and its environmental effects: Recent scientific advances. Atm Environ 146: 1-4.
7. Likens GE \& Butler TJ (2018). Acid rain: Causes, consequences and recovery in terrestrial, aquatic, and human systems. Encyclo of the Anthro 5: 23-31.

8. Galloway JN, Likens GE \& Edgerton ES (1976). Acid precipitation in the northeastern United States: $\mathrm{pH}$ and acidity. Sci 194: 722-723.

9. Evans LS (1984). Botanical aspects of acidic precipitation. The Bot Rev 50(4): 449-490.

10. Xu HQ, Zhang JE, Ouyang Y, Lin L, Quan GM, Zhao BL \& Yu JY (2015). Effects of simulated acid rain on microbial characteristics in a lateritic red soil. Environ Sci Pollut Res 22(22):18260-18266.

11. Calvert JG, Lazrus A, Kok GL, Heikes BG, Walega JG, Lind J \& Cantrell CA (1985). Chemical mechanisms of acid generation in the troposphere. Nat 317(6032): 27.

12. Lefohn AS, Husar JD \& Husar RB (1999). Estimating historical anthropogenic global sulfur emission patterns for the period 18501990. Atmos Environ 33(21): 34353444.

13. Wagh ND, Poonam VS, Sarika BT \& Ingle ST (2006). Biological monitoring of roadside plants exposed to vehicular pollution in Jalgaon city. $J$ Environ Biol 27: 419-421.

14. Bouwman AF, Van DP, Derwent RG \& Michael P (2002). A global analysis of acidification and eutrophication of terrestrial ecosystems. Water, Air, and Soil Poll 141: 349-382.

15. Galloway JN, Dianwu Z, Jiling X \& Likens GE (1987). Acid rain: China United States and a remote area. Sci 236(4808): 1559-1562.

16. Chandru (2006). CHINA: Industrialization pollutes its country side with Acid Rain. Southasiaanalysis.org.

17. Anonymous (1984). Twelve power stations must be cleaned up. Acid News 5-6.

18. Ducros M (1845). Observation d'une pluie acide. J Pharma Chem 3: 273-277.

19. Likens GE, Bormann FH \& Johnson NM (1972). Acid rain. Environment: 
Science and Policy for Sustainable Development 14(2): 33-40.

20. Smith RA (1852). On the air and rain of Manchester. Mem Manch Lit Philos Soc Ser 1: 207e217.

21. Seip HM (2001). Acid Rain and Climate Change-Do These Environmental Problems Have Anything in Common?. Cicerone 6.

22. Seinfeld JH \& Pandis SN (2016). Atmospheric chemistry and physics: from air pollution to climate change. John Wiley \& Sons.

23. Sivaramanan S (2015). Acid rain, causes, effect and control strategies. Cent Environ Autho, Battaramulla.

24. Smith RA (1872). Air and Rain - the Beginnings of a Chemical Climatology. Longmans \& Green, London: 600.

25. Gorham E (1961). Factors influencing supply of major ions to inland waters, with special reference to the atmosphere. Geol Soc Am Bull 72: 795840.

26. Oden S, (1976). The acidity probleman outline of concepts. Water, Air, and Soil Pollution 6: 137-166.

27. Weathers KC, Likens GE \& Butler TJ (2006). Acid rain. Environ Occup Med 4: 1549-1561.

28. Likens GE \& Bormann FH (1974). Acid rain: a serious regional environmental problem. Science 184(4142): $\quad 1176-$ 1179.

29. Overrein LN, Seip HM \& Tollan A (1980). Acid precipitation-effects on forest and fish. Final report of the SNSF-project 1972-1980.

30. Zhao D \& Sun B (1986). Air pollution and acid rain in China. Ambio 15(1): 24.

31. Tamaki M \& Koyama I (1991). The acid rain observed on ground level in Japan. J Jap Soc Air Pol 26(1): 1-22.

32. Galloway JN \& Whelpdale DM (1980). An atmospheric sulfur budget for eastern North America. Atmos Enviro 14(4): 409-417.

33. Rennenberg H \& Gessler A (2001). Acid rain. Nature Encyclo Life Sci.

34. Baedecker PA, Reddy MM, Reimann KJ \& Sciammarella CA (1992). Effects of acidic deposition on the erosion of carbonate stone. Atmos Environ 26(2): 147-158.

35. Lower SK (1999). Introduction to acidbase chemistry. Libro de texto introductorio de química, Simon Fraser University.

36. Driscoll CT, Lawrence GB, Bulger AJ, Butler TJ, Cronan S, Eagar C \& Weathers KC (2001). Acid rain revisited: advances in scientific understanding since the passage of the 1970 and 1990 Clean Air Act Amendments. Hubbard Brook Research Foundation. Science Links' Publication 1.

37. Cullis CF \& Hischler MM (1980). Atmospheric Sulphur: Natural and manmade sources. Atmos Environ 14: 12631278.

38. Kulp JL \& Herrick CN (1987). NAPAP (National Acid Precipitation Assessment Program) Interim Assessment: The Causes and Effects of Acid Deposition. US Government Printing Office, Washington 1: 1-53.

39. Kulp JL (1990). Acid rain: Causes, effects and control. Regulation 13: 41.

40. Kumar S (2017). Acid Rain-The Major Cause of Pollution: Its Causes, Effects. Inter J Appl Chem 13(1): 53-58.

41. Sharma BK \& Kaur H (1994). Environmental Chemistry. India, Krishna Prakashan 4

42. Abrahamsen G, Stuanes AO \& Tveite, B (1983). Effects of long range transported air pollutants in Scandinavia. Water Quality Bull 8(2): 89-95.

43. Scherbatskoy T \& Klein RM (1983). Response of Spruce and Birch Foliage to Leaching by Acidic Mists. J Environ Qual 12(2): 189-195.

44. Sheppard LJ, Crossley A, Parrington J, Harvey FJ \& Cape JN (2001). Effects of simulated acid mist on a Sitka spruce forest approaching canopy closure: significance of acidified versus nonacidified nitrogen inputs. Water Air and Soil Poll 130: 953-958.

45. Asthana DK \& Asthana W (2001). Environment: Problems and Solutions. S Chand and Company Ltd, New Delhi 4. 
46. Verma A, Tewari A \& Azami A (2010). An impact of stimulated acid rain level on different $\mathrm{pH}$-levels on some major vegetable plants in India. Rep and Opin 2(4): 38-40.

47. Tomlinson GH (1983). Air pollutants and forest decline. Environ Sci Technol 17(6): 246-256.

48. Santos BF, Silva LC, Azevedo AA, Araujo JM, Alves EF, Silva EA \& Aguiar R (2006). Effects of simulated acid rain on the foliar micromorphology and anatomy of tree tropical species. Environ Exp Bot 58:158-168.

49. Tift S. (1985). Requiem for the forest. Time 126: 46-53.

50. Schuster PF, Reddy MM \& Sherwood SI (1994). Effects of acid rain and sulfur dioxide on marble dissolution. Materials Performance 33(1): 76-80.

51. Charola AE (1987). Acid rain effects on stone monuments. J Chem Educ 64(5): 436.

52. Keuken MP, Bakker FP, Mols JJ, Broersen B \& Slanina J (1990). Atmospheric deposition and conversion of ammonium to nitric acid on a historic building: a pilot study. Inter J Environ Ana Chem 38(1): 47-62.

53. Okochi H, Kameda H, Hasegawa SI, Saito N, Kubota K \& Igawa M. (2000). Deterioration of concrete structures by acid deposition-an assessment of the role of rainwater on deterioration by laboratory and field exposure experiments using mortar specimens. Atmos Environ 34(18): 2937-2945.

54. Tolba MK (1983). Acid rain a growing concern of industrialized countries. Water Quality Bull 8: 115120.

55. Sersale R, Frigione G \& Bonavita L (1998). Acid depositions and concrete attack: main influences. Cem Con Res 28(1): 19-24.

56. Dutt P (1984). Delhi gasps for its air. Mazingira 8: 10-11.

57. Kitamura S \& Ikuta K (2001). Effects of acidification on salmonid spawning behavior. Water, Air, and Soil Poll 130: 875-880.

58. Nagae M, Ogawa K, Kawahara A, Yamaguchi $\mathrm{M}$, Nishimura $\mathrm{T}$ \& Ito $\mathrm{F}$ (2001). Effect of acidification stress on endocrine and immune functions in carp, Cyprinus carpio. Water, Air, and Soil Poll 130: 893-898.

59. Krug EC \& Frink CR (1983). Acid rain on acid soil: a new perspective. Sci 221(4610): 520-525.

60. Rodhe H, Dentener F \& Schulz M (2002). The global distribution of acidifying wet deposition. Environ Sci Technol 36(20): 4382-4388.

61. Koptsik GN, Koptsik SV \& Aamlid D (2001). Pine needle chemistry near a large point SO 2 source in northern Fennoscandia. Water, Air, and Soil Poll 130: 929-934.

62. Likens GE, Driscoll CT \& Buso DC (1996). Long-term effects of acid rain: response and recovery of a forest ecosystem. Sci 272(5259): 244-246.

63. Likens GE, Driscoll CT, Buso DC, Mitchell MJ, Lovett GM, Bailey SW \& Alewell C (2002). The biogeochemistry of sulfur at Hubbard Brook. Biogeochem 60(3): 235-316.

64. Liu Z, Li D, Zhang J, Saleem M, Zhang Y, Ma R \& Wei H (2020). Effect of simulated acid rain on soil $\mathrm{CO} 2, \mathrm{CH} 4$ and $\mathrm{N} 2 \mathrm{O}$ emissions and microbial communities in an agricultural soil. Geoderma 366: 114222.

65. Breemen V, Driscoll CT \& Mulder J (1984). Acidic deposition and internal proton sources in acidification of soils and waters. J Nat 307(5952): 599.

66. Francis AJ (1982). Effects of acidic precipitation and acidity on soil microbial processes. Water, Air, and Soil Poll 18: 375-394.

67. Killham K, Firestone MK \& McColl JG (1983). Acid Rain and Soil Microbial Activity: Effects and Their Mechanisms . J Environ Qual 12(1): 133-137.

68. Watmough SA \& Dillon PJ (2003). Base cation and nitrogen budgets for a mixed hardwood catchment in southcentral Ontario. Ecosyst 6(7): 675-693.

69. Dai Z, Liu Y, Wang X \& Zhao D (1998). Changes in $\mathrm{pH}, \mathrm{CEC}$ and exchangeable acidity of some forest soils in southern China during the last 32-35 years. Water, Air, and Soil Poll 108: 377-390.

70. Tamm CO \& Hallbäcken L (1988). Changes in soil acidity in two forest 
areas with different acid deposition: 1920s to 1980s. Ambio 56-61.

71. Dickson W (1978). Some effects of the acidification of Swedish lakes. Inter Vere Theor Ange Limno: Verhandlungen 20(2): 851-856.

72. Ferenbaugh RW (1975). Acid rain: biological effects and implications. Envtl Aff 4: 745.

73. Watt WD, Scott CD \& White WJ (1983). Evidence of acidification of some Nova Scotian Rivers and its impact on Atlantic Salmon, Salmo solar. Can J Fish Aquat Sci 40(4): 462-473.

74. Carrick TR (1979). The effect of acid water on the hatching of salmonid eggs. J Fish Biol 14(2): 165-172.

75. Parks PJ (2007) Water pollution. KidHaven Press.

76. Whelpdale DM (1983). Acid deposition, distribution and impact. Water Quality Bulletin 8(2): 72.

77. Berlekom M (1985). Frogs. Acid Magazine 3: 11-12.

78. Wright RF \& Henriksen A (1983). Restoration of Norwegian lakes by reduction in sulphur deposition. Nat 305(5933): 422.

79. Findlay DL \& Kasian SE (1986). Phytoplankton biomass, succession and composition in lake. Experimental lakes area, north eastern Ontario. Can J Fish Aquat Sci 44: 35-46.

80. Roff JC \& Kwiatkowski RE (1977). Zooplankton and zoobenthos communities of selected northern Ontario lakes of different acidities. Can J Zool 55(6): 899-911.

81. Grahn O (1977). Macrophyte succession in Swedish lakes caused by deposition of airborne acid substances. Water, Air, and Soil Poll 7(3): 295-305.

82. Nilssen JP (1980). Acidification of a small watershed in southern Norway and some characteristics of acidic aquatic environments. Internationale Revue der gesamten Hydrobiologie und Hydrographie 65(2): 177-207.

83. Singh B \& Agrawal M (2004). Impact of simulated acid rain on growth and yield of two cultivars of wheat. Water, Air, and Soil Poll 152(1-4): 71-80.

84. Murray AM, Percival DC \& Stratton GW (2004). Impact of simulated acid rain on photochemistry, morphology, and yield of the wild blueberry (Vaccinium angustifolium Ait.). Can $J$ plant Sci 84(3): 877-880.

85. DeHayes DH, Schaberg PG \& Strimbeck GR (2001). Red spruce (Picea rubens Sarg.) cold hardiness and freezing injury susceptibility. Springer, Dordrecht 495-529.

86. Lazarus BE, Schaberg PG, Hawley GJ \& DeHayes DH (2006). Landscapescale spatial patterns of winter injury to red spruce foliage in a year of heavy region-wide injury. Can $J$ For Res 36(1): 142-152.

87. Lechowicz MJ (1982). The effects of simulated acid precipitation on photosynthesis in the caribou lichen Cladina stellaris (Opiz) Brodo. Water, Air, and Soil Poll 18: 421.

88. Neufeld HS, Jernstedt JA \& Haines BL (1985). Direct foliar effects of simulated acid rain: I Damage, growth and gas exchange. New Phytol 99(3): 389-405.

89. Evans LS \& Lewin KF (1981). Growth, development and yield responses of pinto beans and soybeans to hydrogen ion concentrations of simulated acidic rain. Environ Exp Bot 21(1): 103-113.

90. Strayer RF \& Alexander M (1981). Effects of Simulated Acid Rain on Glucose Mineralization and Some Physicochemical Properties of Forest Soils. J Environ Qual 10(4): 460-465.

91. Johnson DW \& Reuss JO (1984). Soilmediated effects of atmospherically deposited sulphur and nitrogen. Philosophical Transactions of the Royal Society of London. B Biol Sci 305(1124): 383-392.

92. Keane KD \& Manning WJ (1988). Effects of ozone and simulated acid rain on birch seedling growth and formation of ectomycorrhizae. Environ Poll 52(1): 55-65.

93. Maehara N, Kikuchi J \& Futai K (1993). Mycorrhizae of Japanese black pine (Pinus thunbergii): protection of seedlings from acid mist and effect of acid mist on mycorrhiza formation. Can J Bot 71(12): 1562-1567.

94. Porter JR \& Sheridan RP (1981). Inhibition of nitrogen fixation in alfalfa by arsenate, heavy metals, fluoride, and 
simulated acid rain. Plant PhysioL 68(1): 143-148.

95. Gunther AJ (1988). Effect of simulated acid rain on nitrogenase activity in the lichen genus Peltigera under field and laboratory conditions. Water, Air, and Soil Poll 38: 379-385.

96. Smol JP \& Glew JR (1992). Palcolimnilogy. Encyclopedia of earth system science. Taylor and Francis, London 95-107.

97. Tolba MK (1983). Acid rain a growing concern of industrialized countries. Water Quality Bull 8: 115120.

98. Thornton I \& Plant J (1980). Regional geochemical mapping and health in the United Kingdom. J Geol Soc 137(5): 575-586.

99. Lynn DA \& Reist PC (1976). Air pollution: threat and response. Physics Today 29: 50.

100. Okita T (1983). Acid precipitation and related phenomena in Japan. Water Quality Bull 8: 101-108.

101. Martin HC (1989). The linkages between climate change and acid rain. Elsevier Sci, New York 59-78.

102. Khemani LT, Momin GA, Naik MS, Rao PP, Kumar R \& Murty BV (1985).
Impact of alkaline particulates on $\mathrm{pH}$ of rain water in India. Water, Air, and Soil Poll 25(4): 365-376.

103. Singh A \& Agrawal M (2007). Acid rain and its ecological consequences. $J$ Environ Biol 29(1): 15.

104. Stoddard JL, Jeffries DS, Lükewille A, Clair TA, Dillon PJ, Driscoll CT \& Kemp A (1999). Regional trends in aquatic recovery from acidification in North America and Europe. Nat 401(6753): 575.

105. Evans CD, Cullen JM, Alewell C, Kopácek J, Marchetto A, Moldan F \& Wright R (2001). Recovery from acidification in European surface waters. Hydrol Earth Syst Sci Discuss 5(3): 283-298.

106. Stoddard JL, JS Karl, Deviney FA, DeWalle DR, Driscoll CT, Herehy AT, Kellogg JH, Murdoch PS, Webb JR \& Webster KE (2003). Response of surface water chemistry to the clean air act amendments of 1990. Environmental Protection Agency.

107. Alcamo J, Shaw RW \& Hordijk L (1991). The RAINS model of acidification: science and strategies in Europe. Kluwer, Dordrecht. 